\title{
Lusioersily
}

\section{Women on the walls: Representations of women in political murals in Northern Ireland}

Rolston, W. (2018). Women on the walls: Representations of women in political murals in Northern Ireland. Crime, Media, Culture, 14(3), 365-389. https://doi.org/10.1177/1741659017718037

Link to publication record in Ulster University Research Portal

\author{
Published in: \\ Crime, Media, Culture
}

Publication Status:

Published (in print/issue): 01/12/2018

DOI:

$10.1177 / 1741659017718037$

\section{Document Version}

Author Accepted version

\section{General rights}

Copyright for the publications made accessible via Ulster University's Research Portal is retained by the author(s) and / or other copyright owners and it is a condition of accessing these publications that users recognise and abide by the legal requirements associated with these rights.

\section{Take down policy}

The Research Portal is Ulster University's institutional repository that provides access to Ulster's research outputs. Every effort has been made to ensure that content in the Research Portal does not infringe any person's rights, or applicable UK laws. If you discover content in the Research Portal that you believe breaches copyright or violates any law, please contact pure-support@ulster.ac.uk. 
Women on the Walls: Representations of Women in Political Murals in Northern Ireland Bill Rolston

All pictures copyright Bill Rolston 2017. For permission to use them please contact author wj.rolston@ulster.ac.uk.

Introduction

There are significantly fewer representations of women than of men in political wall murals in Northern Ireland. This article seeks to examine the extent of this under-representation, as well as to look at the themes involved where such representations do occur in both republican and loyalist murals - themes such as political activism, imprisonment, victimisation, history and mythology. Taken as a whole, these murals present a specific articulation of gender as a dimension of political mobilisation during conflict. Sometimes the images reinforce gender role expectations and norms and on occasion challenge them. As we shall see, the reinforcement and challenge are not shared equally between republican and loyalist murals. Understanding the skewed nature of representation requires the consideration of a number of relevant contexts. It is to those contexts that we turn first.

\section{Women in Northern Ireland}

Despite advances in recent decades, women in Northern Ireland have not achieved economic equality with men. For example, while women's participation rate in paid employment grew from $56.8 \%$ in 1971 to $70 \%$ in 2005 , this has not led to income equality. Because much of 
this growth has been in part-time rather than full-time employment, 'women's median weekly gross earnings in Northern Ireland are on average $29 \%$ below that of men's earnings' (Murphy 2011: 2).This statistical exercise could be continued across a range of issues women's representation on public bodies, gender segregation in the workforce, responsibilities for childcare, political representation, etc. (see Potter 2014) - and the statistics would consistently confirm the existence of inequality.

Beyond the statistics, the situation of women is determined in significant ways by a range of deep structures in the society which derive ultimately from the colonial history of the island. The power of the churches to influence the minds and behaviour of the majority of the population has been highly significant. In the case of the Catholic Church the origins of this power lie in the 'devotional revolution' which followed the disastrous Famine on the mid-19th century (Larkin 1972). Even though the legitimacy of the Catholic Church in particular has been severely dented recently as a result of revelations of child sexual abuse, a profound conservatism in relation to moral, and especially sexual, issues remains. Many of the political parties on the island, north and south, are also conservative on these issues. For example, at the height of the conflict in the North, when communal divisions were most pronounced, opposition to abortion was possibly the only issue which could lead to cross-party cooperation. Abortion remains illegal in the vast majority of cases in Ireland, north and south.

Women and Conflict in Northern Ireland

Gender expectations in society are that men will display 'toughness, autonomy, aggression, rationality, confidence and (hetero)sexuality' and women 'sensitivity, (inter)dependence, passivity, emotionality, quietness, innocence, grace, caring and purity' (Sjoberg 2016: 5). These expectations feed directly into views of war which are as a result highly gendered 
affairs. Men are the warriors and heroes and are expected to step up to the mark to defend the group, the region or the nation. Women on the other hand are allocated two main roles: that of victim, and that of carer, holding the home and family together against the odds. One rationale for men's fighting is defence of the women of the group or nation who are incapable of defending themselves. This rationale becomes most telling when the nation is represented as female; defence of the mother country and defence of actual living mothers and other females thus merge into one rhetorical justification of warfare.

What is missed in this representation is the specificity of the burden of conflict on women. The female non-warrior not only has the caring tasks during the war with children, the old and the injured, but has to continue with these and further tasks long after the war has ended (Sjoberg 2016: 15), in particular surviving widowhood or caring for or suffering the violence of traumatised ex-soldiers. Because neither of these roles entail direct involvement in violence, they do not have the status accorded to the role of soldiers.

In addition, the narrowness of a representation of 'soldiering' which ignores the role that some women play is problematic. Soldiering in terms of the bearing of arms is the public face of conflict. But the 'private' support of women in the home or the community, often dismissed as 'auxiliary', can be at least as important in sustaining conflict. This is likely to be even more significant in the case of asymmetric warfare than in full-scale wars. Yet here, as in other social situations, the private world of women is less valorised than the public world of men.

Finally, an important aspect missing in the bifurcated view of gender and warfare is that there are in fact women soldiers. Admittedly they are in a minority, but in some conflicts their presence has been significant - approximately one-third of the combatants in the FARC in Colombia (Koth 2005), the EPLF in Eritrea (Pankhurst n.d.), the Tamil Tigers in Sri Lanka 
(Alison 2004: 450) and CPN fighters in Nepal (Fontanella-Khan 2009) have been women. In many cases their combat roles have been equivalent to those of males, to the point where they claim to experience an equality under arms which broke radically with traditional gender relations in their society (Farr 2002). For many, however, things changed radically when the conflicts ended. In Eritrea, for example, 'the return to peace, for men, meant a desire for normality and for traditional values. These included women behaving like women, not like men ...' (Pankhurst n.d.,: 5).

For all their contribution, female combatants are ultimately not seen as being on a par with males. These views ultimately derive from the presumption that there is something fundamentally unnatural about women's participation in violence generally and not just during warfare. Put simply, men who kill may be psychopaths or in other ways disturbed, but women who kill are in addition judged to be unnatural, abandoning their feminine essence as passive, emotional, caring persons.

The conflict in Northern Ireland between 1968 and 1998 was a three-way affair involving republicans, loyalists and security forces, the British army and the local police force, the Royal Ulster Constabulary. All were armed and all suffered and inflicted casualties. The failure of a civil rights campaign in the 1960s marked a turn to armed activity on all sides, and this only came to an end with an all-party peace agreement, the Good Friday Agreement, in 1998. This led to the establishment of a devolved parliament and executive for the first time since 1972, the early release of politically-motivated prisoners, the reform of the police, the departure of all but a garrison force of the British army and ultimately the decommissioning of weapons by the various non-state military groups and the disbandment of some of them. 
Female combatants in Northern Ireland constituted a minority of all combatants. Statistics on politically motivated prisoners provide evidence of this. There were an estimated 1018 politically motivated female prisoners between 1972 and 1998 (Corcoran 2006: 9), in a situation where at least 15,000 republican men and 5,000-10,000 loyalist men served prison sentences (Shirlow and McEvoy 2008: 2). The bulk of the female prisoners were republican. The number of loyalist female prisoners was always low; in the 1990s there were not enough members of either the UDA or the UVF (the two main loyalist paramilitary groups, Ulster Defence Association and Ulster Volunteer Force respectively) to allow them to maintain formal structures in the prison (Corcoran 2006: 131). McEvoy (2009: 270) is alone among researchers in claiming that loyalists could boast 'approximately two dozen active women's units at various times throughout the conflict with a combined membership as high as three thousand women' and that women 'accounted for 2 percent of the UVF membership across the thirty-year conflict'.

Loyalist women's activism was almost entirely confined to auxiliary roles: ' $\ldots$ in general loyalist women carried the guns and loyalist men used them ... the presence of a few combatant women seems to have been received by many men as a significant threat or challenge...' (Alison 2004: 456). There is evidence that in the early days of the Provisional IRA republican women activists experienced similar sexism (Alison 2004: 456). However, the republican movement had a separate well-established women-only organisation, which carried out auxiliary functions. Occasionally some of its members were seconded into the IRA. Many complained about this lesser status and demanded full equality in military terms. Eventually, after IRA restructuring, some women were accepted into the IRA on an equal 
basis with men (Ward 1989: 258-259). Some went as far as to say that there was more equality and greater opportunity in the military wing than in the political wing at this time (Bloom et al. 2012: 72).

Few of these women claimed to have been motivated by feminism in bidding for equality in military terms (Bloom et al. 2012: 72). At the same time, it was clear that many of them rejected the traditional conservatism of republicanism which historically had determined that their role was solely auxiliary (Ward 1989). One of the most senior female republican IRA members, Mairéad Farrell, killed on active service by the SAS in Gibraltar in 1988, rejected the role model of Mother Ireland, patient and long-suffering, in the memorable phrase: 'Mother Ireland, get off our backs!' ${ }^{1}$ Despite such sentiments, not all feminists in Northern Ireland rushed to support combatants/prisoners such as Farrell. In fact, the issue of the conflict proved a highly divisive one for feminism. Many in the Northern Ireland Women's Rights Movement focused on the male domination in republican organisations and found it difficult to support women who had thrown in their lot with patriarchal military organisations. Some members left to form the Socialist Women's Group. It and Women Against Imperialism took an anti-imperialist position on the conflict and consequently supported republican women while being critical of patriarchy within the wider maledominated organisations. The Belfast Women's Collective attempted to maintain links with each side but often ended up being criticised by both. Few feminists had any links with loyalist women (Rooney 1995; Roulston 1989; Ward 1991). Later the Northern Ireland Women's Coalition had a brief but significant influence on the merging peace process by adopting in effect an agnostic position on the national question (Fearon 1999).

\footnotetext{
${ }^{1}$ She spoke these words in an interview for the film Mother Ireland, Derry Film and Video Collective 1988.
} 
Republican women's activism extended far beyond direct military involvement. Women were prominent in the Green Cross which collected and distributed money for the support of prisoners' families. During the prison protests of the late 1970s support came from the Relatives' Action Committees which were overwhelmingly made up of women, many of them directly related to the prisoners. In the prison hunger strikes which followed, a number of prominent members of the H Blocks/Armagh Committee were women, one of whom, Miriam Daly, was assassinated and another of whom, Bernadette McAliskey, survived an assassination attempt.

Beyond the activists, women civilians were also victims of the conflict. Based on Sutton (1994), women constituted around $10 \%$ of the direct victims of the Northern Ireland conflict. ${ }^{2}$ The percentage of women among the 47,541 people injured is unknown. ${ }^{3}$ Women also accounted for a large but unknown number of indirect victims - widows, mothers of dead children, carers of the injured, internally displaced people, etc. The representation of female victims of war and political conflict has been criticised by many authors (Yuval-Davis and Anthias 1989); some have emphasised the way in which women have been infantilised in this representation (Stringer 2014: 27-32). Women victims of conflict have been increasingly relegated to a limited number of discrete categories: the passive refugee, the waiting wife, the rape survivor (Del Zotto 2002). The underlying trope in this representation is the implicit understanding that victimhood equals lack of agency; passivity is the essence of (female) victimhood. While it is undeniable that the ways in which women as mothers, daughters, sisters are often left to pick up the pieces of the lives of others devastated in events they did not chose, the interpretation does not allow for the very real forms of women's agency in conflict.

\footnotetext{
${ }^{2} \mathrm{http} / / /$ www.wesleyjohnston.com/users/ireland/past/troubles/troubles_stats.html\#gender

${ }^{3}$ RUC/PSNI statistics: Table NI-SEC-05: Persons injured (number) due to the security situation in Northern Ireland (only), 1969 to 2003: http://cain.ulster.ac.uk/ni/security.htm\#05.
} 
In addition, there were a number of popular peace movements composed mostly or entirely of women, most notably the Peace People (Hammond-Callaghan 2011). There were also individual women who came to prominence for their agency in opposition to conflict - Nobel Peace Prize winners Mairead Corrigan and Betty Williams, the McCartney sisters taking on republicans over the killing of their brother (Ashe 2007). While lack of agency cannot be applied to such women, another powerful trope comes into play; against the 'unnaturalness' of violent women, peace women were essentialised as authentic women. Thus leading republican activist Máire Drumm was labelled by the media as the 'grandmother of hate' (O'Keefe 2013: 86), while her contemporary Mairead Corrigan was an 'angel of peace' (Stiehm 2014: 66). In Northern Ireland as elsewhere, the agency of real women as opposed to cyphers in countless community groups, human rights campaigns, victims' associations and justice movements is often missed or underplayed (Restrepo 2016; Haeri and Puechguirbal 2010).

Representation and memorialization of women in public space in Northern Ireland

In line with a widespread trend globally, women are under-represented symbolically in public space in Northern Ireland (Hamber and Palmary 2009). Memorialization in public space is highly gendered, whether in terms of street names or public art installations. The great and the good are recognised: soldiers, colonial administrators, politicians, almost all of them men. Statues of women are not entirely absent; one of Queen Victoria graces the entrance to Belfast City Hall.

There have been attempts recently to correct this virtual invisibility. The City Hall now boasts a stain glass window celebrating the working women of Belfast and there is a statue to working women outside the main bus station. Queen's University's Canada Room has a large 
painting by Michelle Rogers entitled 'Women emerging from the shadows', portraying the role of women throughout the academic institution. There is a larger-than-life figurative female by the river Lagan and a statue of Florence Nightingale at Belfast City Hospital. In 2011, on the centenary of International Women's Day, a mural by artist Rita Duffy was unveiled on the Shankill Road; depicting a stylized feast, it was a celebration of women's fellowship. Finally, as part of a 'Belfast Women's History Tour' in 2014, some streets were temporarily renamed in honour of key women in Belfast history (WRDA 2015: 4).

These innovations are a welcome if partial correction of the standard imbalance in public space. The effects of this imbalance should not be underestimated. Symbols in public space are powerful. They convey a message of who is a cherished citizen. They indicate where power, authority and status lie in society. If women, and more importantly, girls and young women do not see themselves reflected in public representation, this absence sends out a powerful message: only men are important. Coupled with the reality of inequality throughout society, the public landscape plays a key role in establishing and maintaining patriarchal hegemony. Public representation becomes part of the propaganda for patriarchy.

\section{Murals in Northern Ireland}

The tradition of painting political murals predates the partition of Ireland. Beginning in 1908, unionists painted murals on July $12^{\text {th }}$ as part of the annual celebration of the victory of Protestant King William over Catholic King James at the Battle of the Boyne in 1690. Northern Ireland was a one-party state from its inception in 1921 until 1972 and in that scenario the murals, along with the other rituals around 'the Twelfth', were crucial in consolidating unionist solidarity. The rituals were massively male-dominated. The Orange Order marchers on 'the Twelfth' were male; the only female groups permitted to march did so 
at the explicit invitation of the male lodges (Racioppi and O'Sullivan See 2000: 13). The accompanying bands were mainly or exclusively male. And the muralists who painted or repainted the murals each year for the celebrations were men.

While marching or painting on 'the Twelfth' may have been in effect a civic duty for unionists in a unionist state, such a privilege was not extended to nationalists. While there was a vibrant nationalist culture, it was confined to church halls, schools and sports venues in nationalist areas. Public space was for unionism, and in that situation, painting nationalist murals was taboo. That changed radically with the republican hunger strike of 1981; hundreds of murals were painted in nationalist areas supporting the prisoners' demand for political status. After the hunger strike, republicans continued to paint murals on a range of themes, from Irish history and mythology to current affairs and international struggles. Many murals related to their armed struggle, usually depicting armed and hooded IRA members, most of whom were identifiably male.

In the mid-1980s there was a major transformation in unionist mural painting when the commanders of the various loyalist paramilitary groups took over control of the walls in their areas. For a while loyalist murals were virtually monopolised by advertisements for whichever loyalist group commissioned them; they displayed armed and masked men. The fact that republican commanders did not ruthlessly control their walls meant that military murals did not monopolise the genre in republican areas. Later this had implications for the peace process; republican muralists were able to cease painting contemporary armed members on the walls, while the pressure continues to persuade loyalist commanders to cease painting armed men.

During the conflict the function of the murals was to mobilise support for the various political positions of republican and loyalist groups, including support for their respective 'armed 
struggles'. In the peace process there is evidence, especially on the republican side, that the murals play a role in conflict transformation (Rolston 2010). They occur throughout Northern Ireland, mostly in working class areas of the cities and towns. Sometimes they are sitespecific, painted at the location where the issue addressed in the mural occurred; this is often the case for memorial murals. Frequently the murals appear along major thoroughfares and at key junctions, such highly visible sites often being the most sought after by campaign groups. At the same time, many murals occur in more obscure settings - in the middle of working class estates or at the end of cul-de-sacs. For reasons of security during the painting process, it is unusual for murals to be painted at interface areas, where working class loyalist and republican areas abut each other.

The muralists on both sides are untrained and self-taught. The vast majority are men. Only one woman has been known to paint on loyalist walls. The situation is not so stark on the republican side. There have been a number of female muralists and for a time in the early 1990s there was a women-only mural group in Belfast named Síle na Gig, in honour of the Celtic fertility symbol which displays a naked woman sitting, legs akimbo, displaying an enlarged vulva. In this instance at least women's muralism differed markedly from that of men.

Northern Ireland has the longest continuous mural painting tradition in the world, but it is not alone in having political murals. They exist in great numbers throughout Latin America, especially in Colombia, Chile and Venezuela, as well as in Palestine, Iran, Sardinia and the Basque Country. Despite major differences between each of these phenomena, one of the most common themes is memory of past struggles and victimhood, and in particular memorialisation of dead combatants. 


\section{Methodology}

The murals to be discussed here have been selected from a major database of photographs of political murals produced in Northern Ireland since 1981. The total number of separate political murals in the database is 2398 . This does not constitute all the political murals produced during that period. Some were painted in obscure places and were missed in the prolonged collection process. Others were short-lived and were not photographed. For example, one pro-IRA mural on the side of the Sinn Féin offices in Belfast in 1989 was destroyed by the British army six hours after completion. ${ }^{4}$ More generally, murals have been destroyed by the muralists themselves, anxious to use the space for a new mural with a different or updated message. For this reason it was almost impossible, especially in the days before digital photographs were posted online, to access photographs of murals retrospectively. Obtaining photographs required countless hours of 'mural hunting' in real space and time, with the result that sometimes a mural had been replaced before I managed to photograph it.

A political mural is defined here as one with an articulated political message, usually painted not as an exercise in individual expression but as part of a wider political movement. Consequently, the total number of murals noted above does not contain other images in the database which are not political. For a start, most individually produced spraycan street art, whether a simple tag or a more ornate display, is not included. At the risk of contradiction, some text-based messages on walls have been included, especially if they have been painted with some care and attention rather than simply scrawled or sprayed hurriedly. Secondly, murals which are simply on cultural themes are not included. This is a slightly difficult distinction given that many aspects of culture are highly politicised in Northern Ireland -

\footnotetext{
${ }^{4}$ Incidentally, I did manage to get a photograph of this short-lived mural. Photographs of over 400 of the murals in the archive are reproduced in Rolston 1992, 1995, 2003, 2013.
} 
such as Gaelic sports on the nationalist side, or Orange marches on the unionist side. Murals with a politico-cultural intent are included, for example those which claim that the peace process has been eroding unionist culture. Large text-based republican displays on Divis Mountain to the west of Belfast are also excluded. Erected using parachute cloth by a group called Gael Force, they are undeniably political in content, supporting such causes as the release of long-term native American prisoner Leonard Peltier or Palestinian statehood. ${ }^{5}$ However, on the narrow basis that, as the derivation of the word indicates, a mural is on a wall, they are not included. Finally, the murals of the Bogside Artists in Derry are included. The Bogside Artists have been at pains to insist that their murals are not propagandistic (Kelly 2001: 103). However, it is likely that their depiction of hunger strikers, civil rights activists and British soldiers are viewed not only as political but as republican messages. In summary, the final figure of 2398 murals was arrived at by including politically articulated murals from republican and loyalist muralists and the Bogside Artists, as well as some textonly messages, but excluding text-only displays erected on the Belfast hills, spraycan street art, and cultural murals.

Each selected mural was then examined for representations of women - current, historical or mythological. As expected, such representations occurred only in a minority of murals, namely 325 out of the total of 2398 , that is, $13.5 \%$. However, there were stark differences between the two camps. In republican murals, there were 272 which represented women out of a total of 1320 , that is, $21.0 \%$. As for loyalist murals, a mere 53 had representations of women out of a total of 1078 , that is, $0.5 \%$.

The next step was to attempt to categorise these representations. There is a certain amount of choice involved in this process. For example, a number of republican murals were included in

\footnotetext{
${ }^{5}$ https://www.facebook.com/Gael-Force-Art-174957995982116/photos/
} 
a category of 'suffering mothers/sisters', which depicted women with dead or injured menfolk. These could have also been amalgamated into the category of 'victims'. Likewise the category of 'Ulster Scots' in loyalist murals could have been subsumed in the 'historical' category. However, these categories were judged to be specific enough to be disaggregated from the wider categories.

Allocating a mural to a single category sometimes also required choice. Some republican 'activists' were assassinated, thereby being eligible to be categorised also as 'victims'; they were however included in the former category. Likewise some 'political prisoners' were not only 'activists' but also 'victims'; in terms of categorisation priority was given to whichever was judged to be the main political thrust of the mural's message.

Findings

Tables 1 and 2 present the results of this exercise.

\begin{tabular}{|l|l|l|}
\hline Category & Number of murals & \% of murals listed here; $\mathrm{n}=248$ \\
\hline Historical & 58 & 23 \\
\hline Activists & 43 & 17 \\
\hline Volunteers $^{6}$ & 37 & 15 \\
\hline Victims & 23 & 9 \\
\hline International & 22 & 9 \\
\hline Prisoners & 19 & 8 \\
\hline Women's rights & 10 & 4 \\
\hline Mythological & 9 & 4 \\
\hline
\end{tabular}

\footnotetext{
${ }^{6}$ This is the term used by republicans and many loyalists for their combatants.
} 


\begin{tabular}{|l|l|l|}
\hline Suffering mothers/sisters & 9 & 4 \\
\hline Perfidious Albion & 8 & 3 \\
\hline Mother Ireland & 7 & 3 \\
\hline Anti-racism & 6 & 2 \\
\hline
\end{tabular}

Table 1: Themes in republican murals

This represents 248 of the 272 republican murals categorised. The remaining 24 murals fall into a number of miscellaneous categories such as 'peace', 'eradication of poverty' and 'children's rights'.

\begin{tabular}{|l|l|l|}
\hline Theme & Number of murals & $\%$ of murals listed here; $\mathrm{n}=53$ \\
\hline Historical & 15 & 28 \\
\hline Royalty & 11 & 21 \\
\hline Victims & 8 & 15 \\
\hline Empire & 5 & 10 \\
\hline Activists & 4 & 8 \\
\hline Ulster-Scots & 3 & 6 \\
\hline Volunteers & 1 & 2 \\
\hline
\end{tabular}

Table 2: Themes in loyalist murals

This represents 47 of the 53 loyalist murals categorised. The remaining 6 murals fall into a number of miscellaneous categories such as 'culture' and 'peace'.

The remainder of the article will consider each of the themes which emerged from the categorisation exercise in greater detail. 
Volunteers

... the IRA ... has emphasized the importance of women to the movement and constructed one role for women as being that of the 'freedom fighter'. This image has been celebrated in a number of republican street murals (Alison 2004: 454).

The IRA female volunteer is not the most frequent representation of women in republican murals, but it is perhaps the most striking, especially when considered alongside the almost total absence of such representation in loyalist murals. Many of the instances relate to the women-only organisation Cumann na mBan, often linking the organisation in the recent conflict with the original organisation formed in 1913. But the iconography refers less to the auxiliary functions of nurse, courier or weapons handler than to more direct references to insurrection and armed struggle: historical uniformed women marching in unison, other contemporary uniformed women brandishing weapons. This comes through most strongly in two forms. First is the roll of honour which lists dead female republican volunteers alongside male comrades; all are portrayed equally as having fought and died for the cause. Second is the representation of individual volunteers who died in action. By far the most common republican female thus depicted is Mairéad Farrell; she has appeared in at least 13 murals, most of them referring directly or indirectly to her death on active service in Gibraltar.

One mural, entitled 'Resistance', painted on the Falls Road, Belfast in 1982, showed a number of activist women, including one volunteer carrying a heavy machine gun. The accompanying slogan attracted some criticism from feminists within and outside the republican movement at the time: 'We must grow strong but without losing our tenderness'. This statement is attributed to Che Guevara who presumably did not, as this mural implies, intend the message to apply solely to women. Two other murals stand out in terms of foregrounding the military 
role of women. One, in Glenveagh Drive, Belfast in 2000, depicts a female volunteer in uniform, armed with an automatic weapon and flanked by the portraits of four local IRA women, including Mairéad Farrell (see Figure 1). A second mural in Ballymurphy Road Belfast in 2002 also has portraits of local republican women activists, as well as a portrayal of uniformed Cumann na mBan members marching and carrying flags; looming over them is a uniformed, armed woman (see Figure 2).

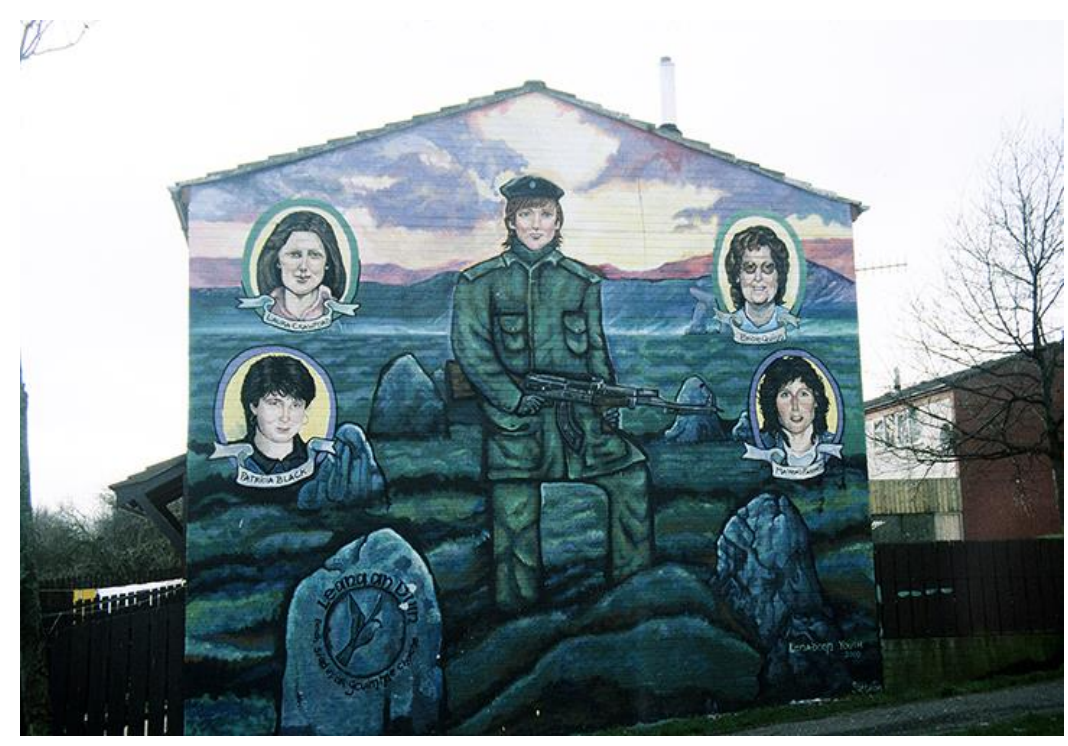

Figure 1. Glenveagh Drive, Belfast 2000

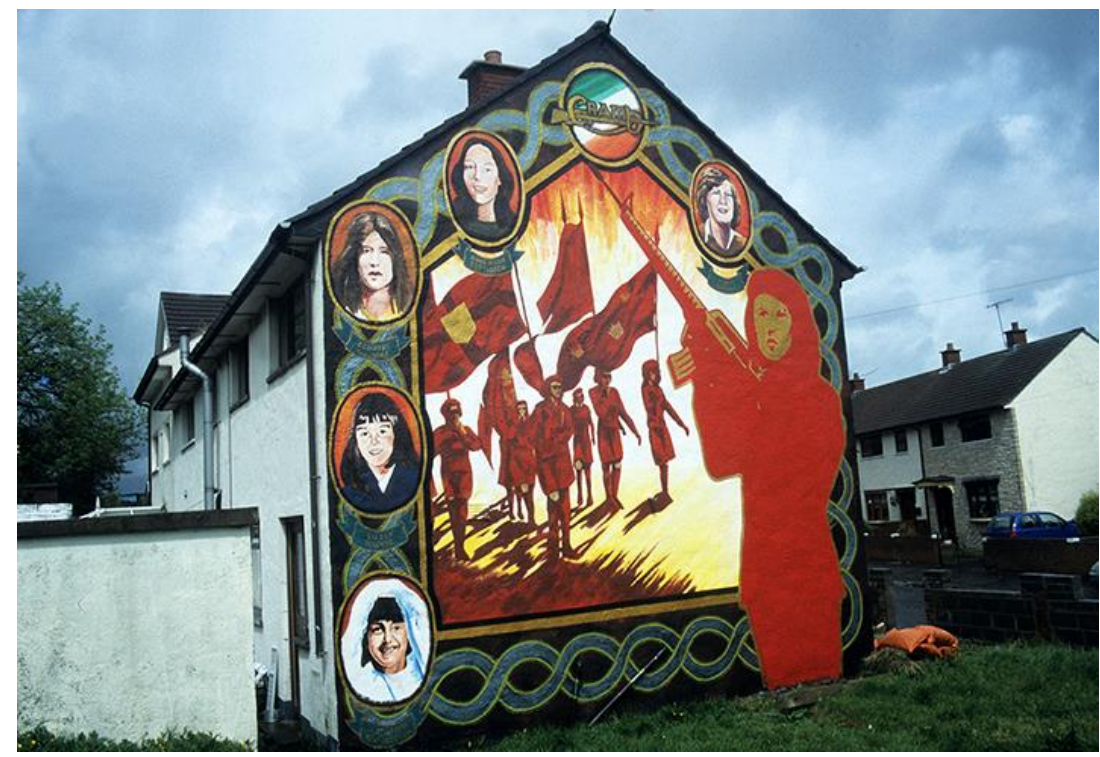

Figure 2. Ballymurphy Road, Belfast 2002 
Only one loyalist mural depicts women in a military role (see Figure 3). Two women and four men stand, uniformed and armed. The men have the heavier weapons and are poised as if to use them. The women, by contrast, seem to be posing with the weapons and for that reason appear less threatening, even if they take centre place in the display.

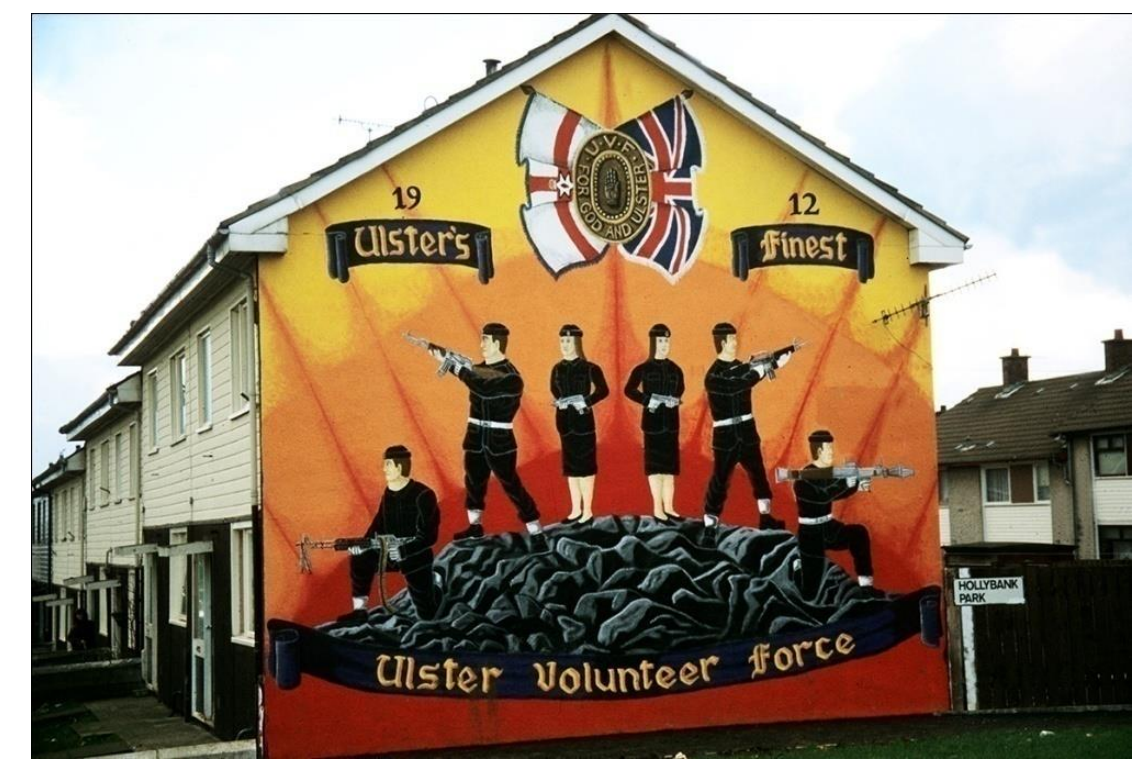

Figure 3. Cashel Drive, Newtownabbey 1996

\section{Activists}

The murals display a range of other ways other than direct military involvement in which women participated in the republican movement. In one mural, an elderly woman carries a rifle in a shopping bag; in another an elderly woman remonstrates with a member of the Parachute Regiment (see Figure 4). A group of smiling white-haired ladies serve sandwiches to an IRA active service group whose rifles are propped against the wall and some women carry banners and flags on demonstrations, while others protest at Orange parades going through nationalist areas. Two women in particular are referred to frequently. Six murals portray Sinn Féin vice-president Máire Drumm; in one she leads a group of women carrying 
groceries as they break a two-day curfew in the Lower Falls Road area imposed by the British army in July 1970. Four murals depict Miriam Daly, leading member of the Irish Republican Socialist Party and key organiser in the H Blocks/Armagh Committee. Both women were assassinated by loyalists, Drumm as she recovered from an operation in hospital in October 1976, and Daly in her own home in June 1980.

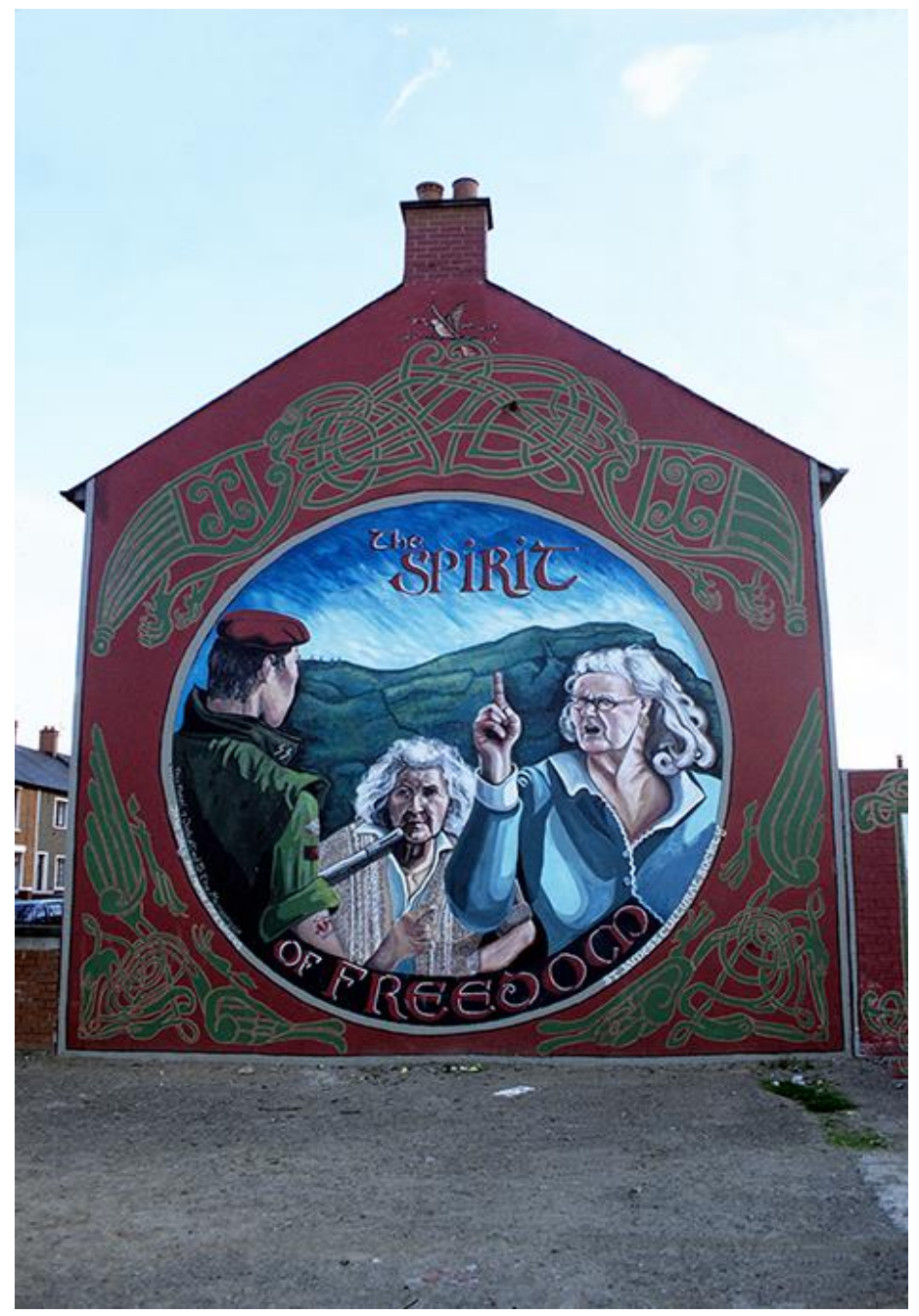

Figure 4. Donegall Road, Belfast 1994

There are two main activities which are significant in these murals portraying women as activists. The first is their role during British army raids. At the first sign of such a raid, women came onto the streets banging binlids repeatedly on the road surface. As many of these raids occurred before dawn, the noise served to waken everyone in the district, thereby 
preparing them for what was to come and allowing IRA volunteers time to escape. At least six murals depicted women with binlids (see Figure 5). The second major activity is the involvement of women in highlighting the plight of politically motivated prisoners on protest in the late 1970s and during the hunger strikes which followed in 1980 and 1981. For a time, women were the only people building this protest, often on behalf of their own partners and sons, wearing blankets on public demonstrations (Ross 2011).

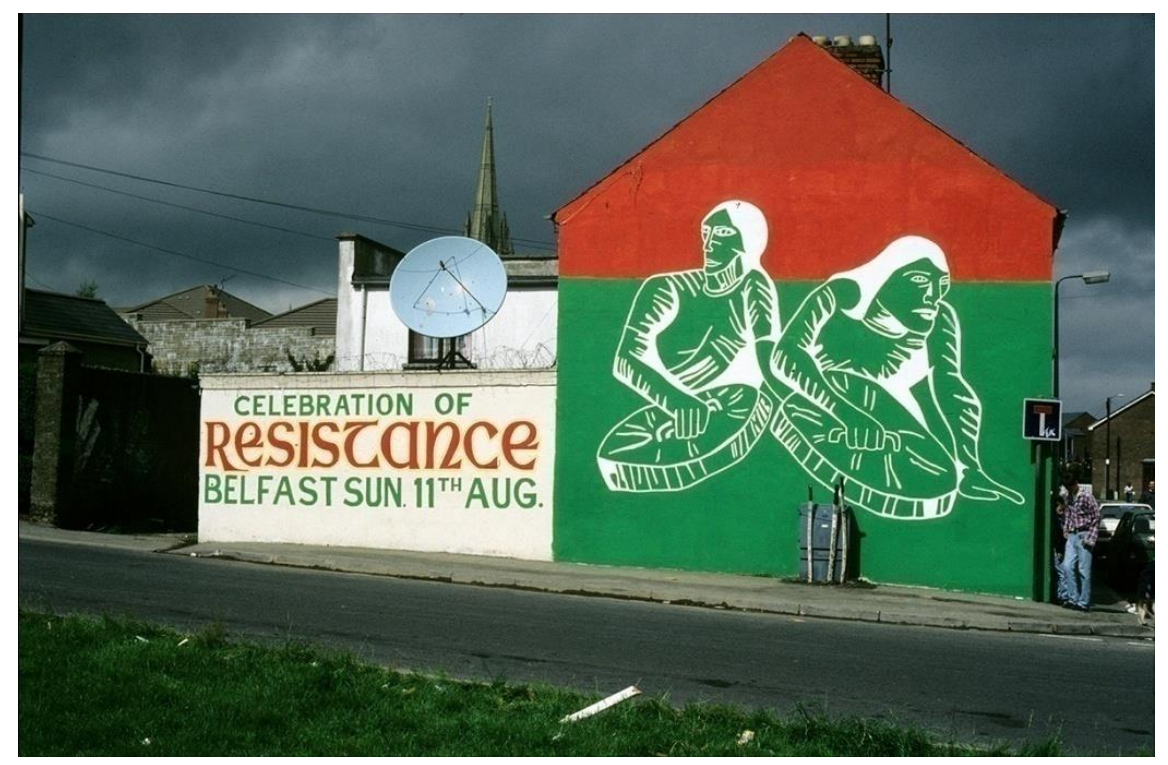

Figure 5. Westland Street, Derry 1991

In stark contrast to the heroic images of female paramilitaries (and women in other public, active roles) in republican street art, there has been no equivalent Protestant symbolic role for women; in the iconography of loyalist political murals, the images are almost entirely masculine (Coulter, 1999: 240-241).

Five loyalist murals depict women activists such as women celebrating the success of the 1974 Ulster Workers' Council Strike which brought down a power-sharing government. Three murals reproduce a postcard from 1914 depicting Ulster as a maiden with a rifle who addresses the viewer: 'Deserted! Well, I can stand alone' (Killen 1985: 72). In two of these 
she is juxtaposed with a woman, scarf hiding her identity, who stands guard while her husband drives a tractor on their farm (see Figure 6). Copied from a newspaper photograph of a unionist farming family near the border, the image supports the claim that unionists were subject to 'ethnic cleansing' by republicans (Patterson 2013).

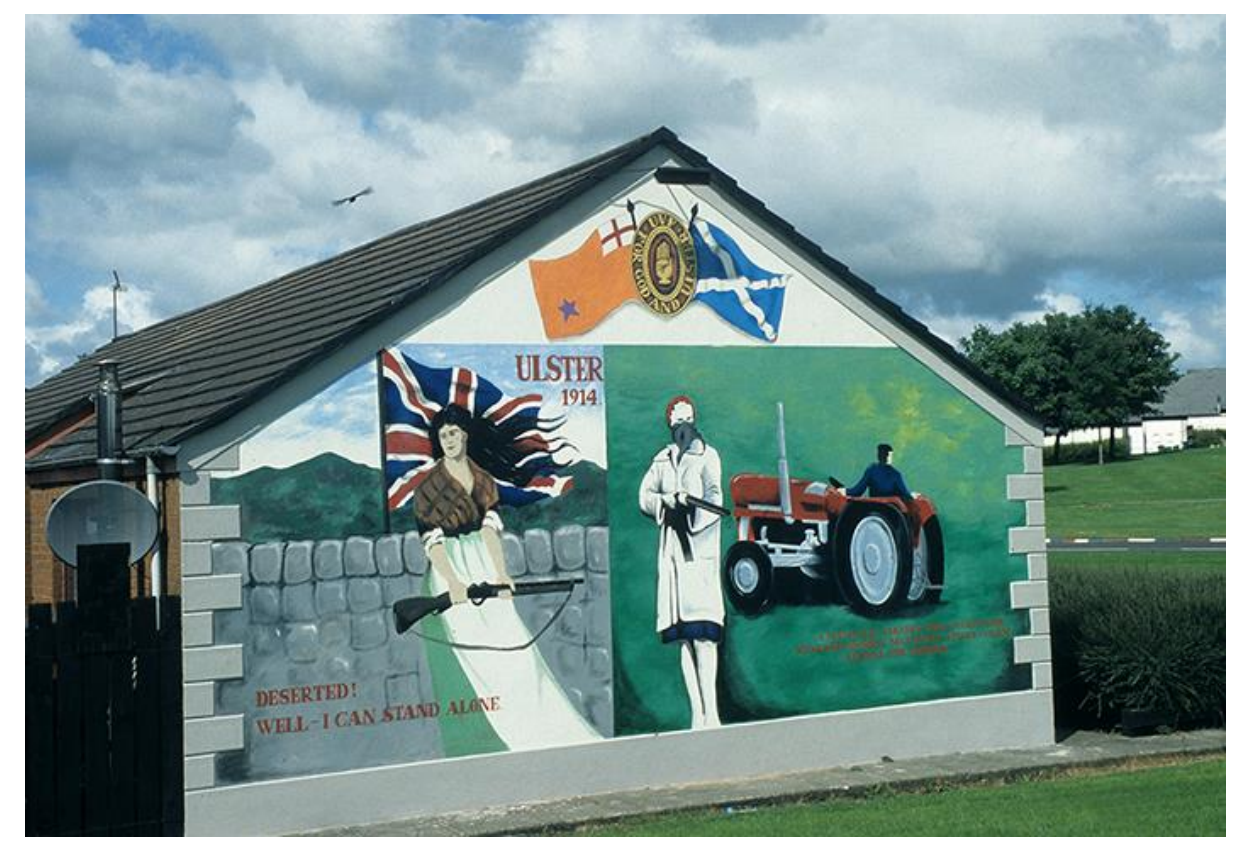

Figure 6. Drumtara, Ballymena 2004

Prisoners

Many female republican activists, volunteers and otherwise, ended up in prison. The women engaged in their own 'dirty protest' in support of political status in Armagh Jail and three women, including Mairéad Farrell, also embarked on a brief hunger strike. Pictures of the protesting women and men were common in republican pamphlets, newspapers and posters. But as the protest developed into hunger striking, it was images of men which came to dominate the most potent public propaganda, the murals. In later years, Farrell would come to be depicted frequently in the company of Kieran Nugent, the first blanketman, and the ten 
hunger strikers who died, but initially the extent of acknowledgement of women prisoners was the painting of slogans saying 'Victory to the Armagh women'.

Republican women prisoners fared rather better after the IRA ceasefire of 1994. Murals proliferated spelling out republican demands, one of which was the release of politicallymotivated prisoners. Many areas had murals which listed local republicans, women and men, currently in prison. In similar fashion, though the central image in Figure 7 is of a male prisoner, the female gazing through the bars is also given prominence.

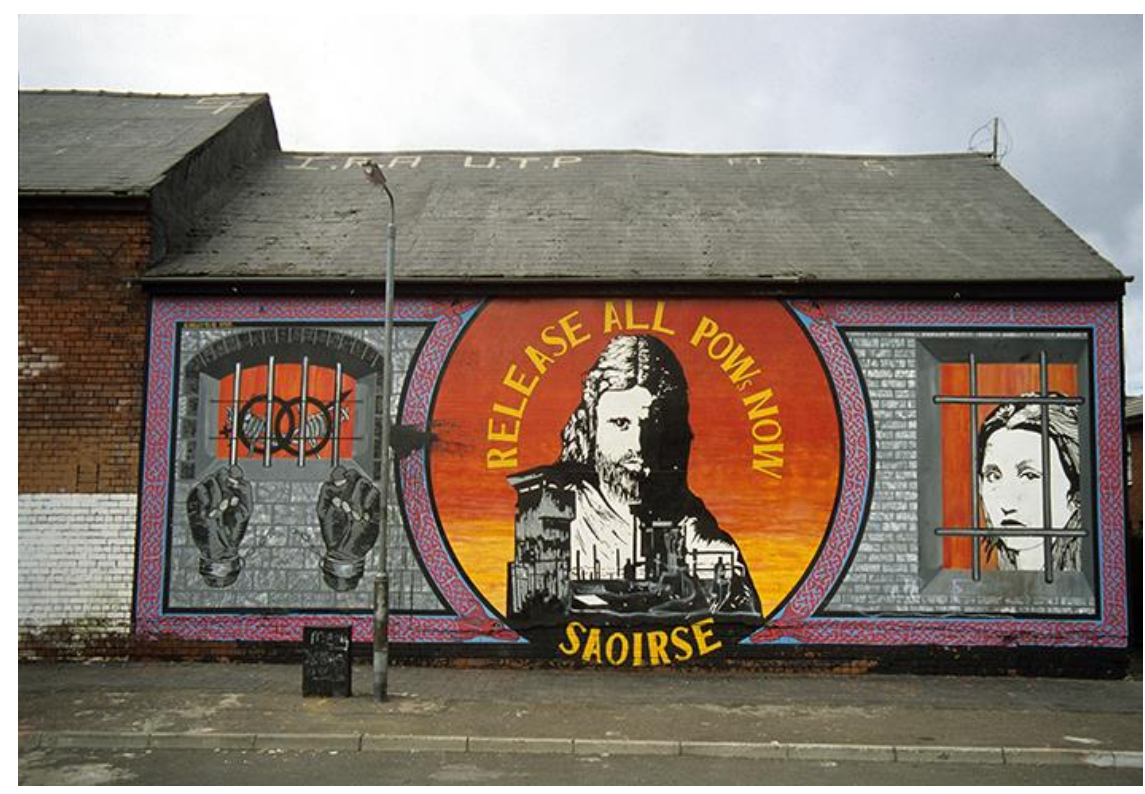

Figure 7. Kinallen Court, Belfast 1995

As the peace process developed after the ceasefire, there were a number of high profile republican women prisoners. Roisin McAliskey was arrested in November 1996 in relation to bombing offences in Germany. Pregnant, asthmatic and dangerously underweight, she pleaded her innocence. A major campaign was organised for her release, which finally came in April 1998 (Whitaker 2008: 7-9). During that campaign, at least two murals were painted in Derry and Belfast (see Figure 8). 


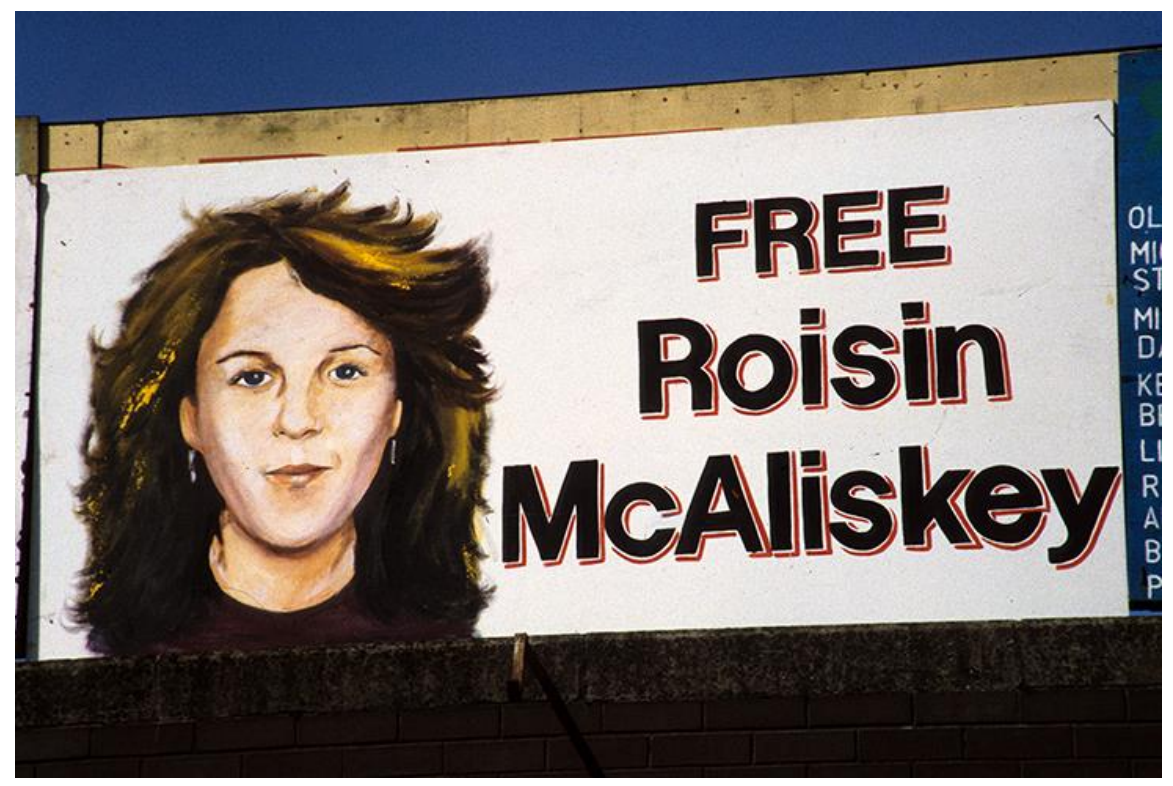

Figure 8. Andersonstown Road, Belfast 1998

Later, at least four murals appeared in Belfast alone as part of the campaign for the release of Marion Price. A long-term activist, she, along with her sister Dolours, had been released from jail in England in 1980 after 200 days on hunger strike, during which they had been force-fed. She was arrested in 2011 on a charge of encouraging support for an illegal organisation. Her health deteriorated rapidly. She was released in May 2013.

Given the virtual absence of women combatants on the loyalist side, and consequently the miniscule number of loyalist women prisoners, it should not be surprising that there have been no loyalist murals depicting women prisoners.

\section{Victims}

As with men, women experienced direct violence from a range of sources: bombs, targeted shootings, crossfire, riots, intimidation, beatings, etc. For republican muralists the main focus is on violence inflicted on women by the British army and police, and especially the latter. The issue of rubber and plastic bullets in particular is highlighted in nine murals. These 
caused the deaths of 17 people, over half of whom were children. A number of the child victims were girls, such as Julie Livingstone (aged 14) and Carol Ann Kelly (aged 11), both killed in 1981 and both memorialised in separate murals. A particularly striking mural on the subject painted in Twinbrook Road, Dunmurry in 2000 does not portray actual victims, but juxtaposes children's enjoyment of play with the lethal force of the police. The visual reference to 'Schindler's List' is not accidental (see Figure 9).

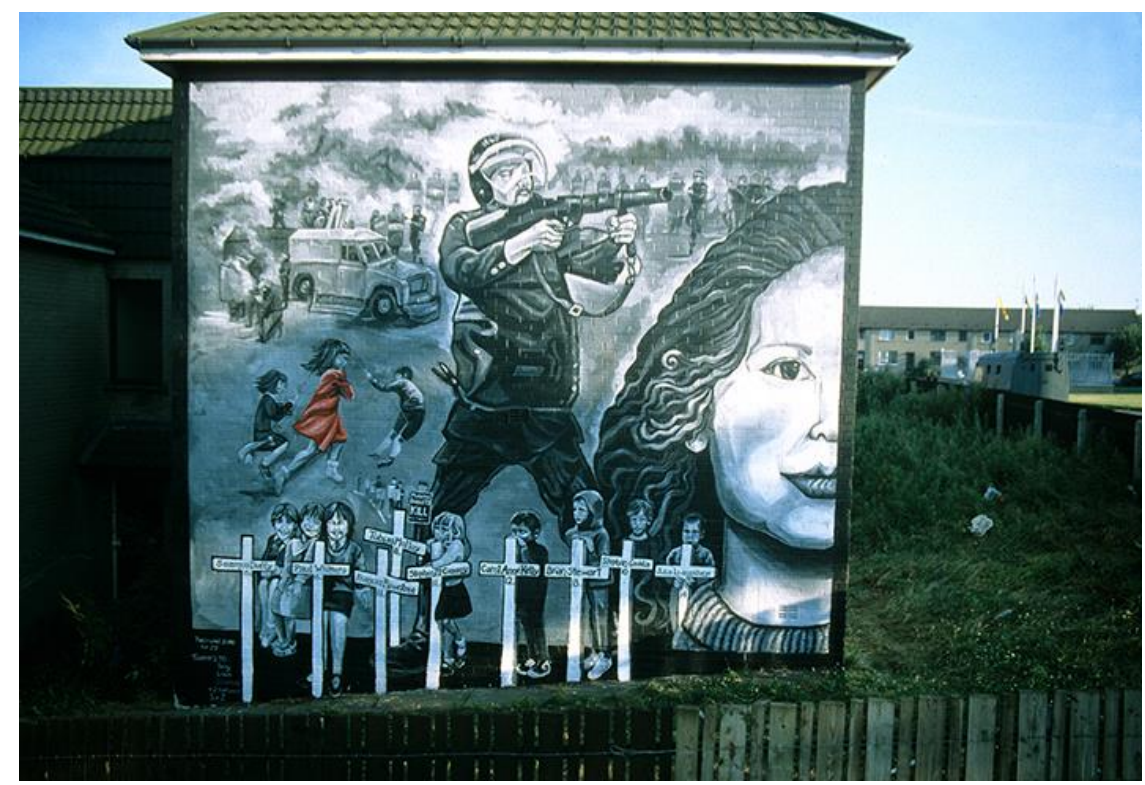

Figure 9. Twinbrook Road, Dunmurry 2000

Other victims are memorialised: the 11 women and men who died at the hands of the Parachute Regiment in Ballymurphy in August 1971, the four victims, including 13 year old Margaret Gargan, killed by British soldiers in West Belfast in July 1972. Loyalist violence or its threat is also treated. Women and men duck for cover as loyalist Michael Stone attacks the funeral of the three IRA members killed in Gibraltar in 1988, killing three mourners; schoolgirls are forced to run a gauntlet of loyalists each morning on their way to Holy Cross primary school in Ardoyne in 2001; three Irish dancing girls on Garvaghy Road are dwarfed by a gigantic Orangeman in bowler hat and sash, holding a petrol bomb. In at least one 
instance, the way in which loyalist and state violence come together is highlighted. As riot police forced back residents to ensure that an Orange parade passed down Garvaghy Road in 2000 women were among the injured (see Figure 10).

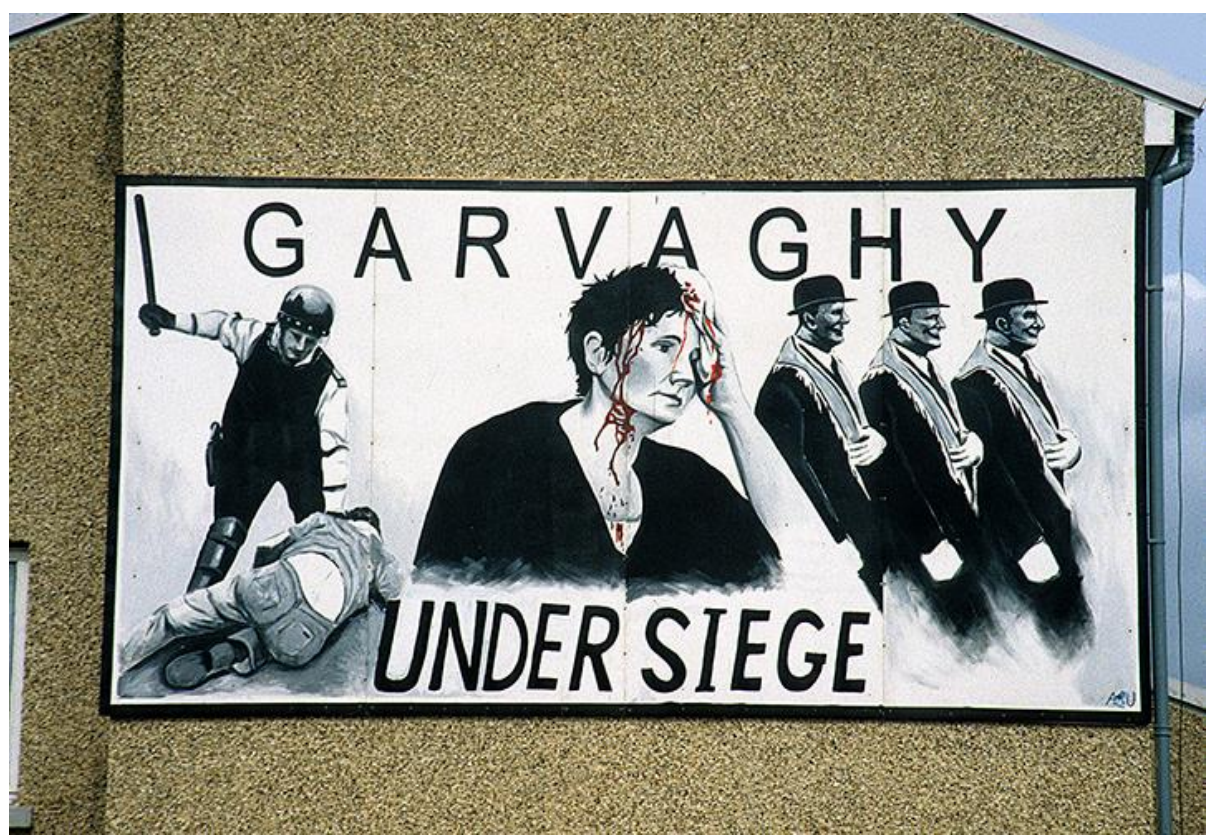

Figure 10. Garvaghy Road, Portadown 2000

Some of the most poignant murals portray the anguish of mothers, wives and sisters. In a Pieta-like image during the hunger strike in 1981, a man holds a dead hunger striker in his arms while the mother looks on, and in later commemorative murals of the hunger strike the wife and child of Joe Doherty in one instance and the parents of Kieran Doherty in another are represented. Consciously or otherwise, some of these murals recall to mind the words of Patrick Pearse's poem, 'The Mother', written the night before his execution in 1916: 'Lord, thou art hard on mothers./We suffer in their coming and their going.' The stark difference between loyalist and republican iconography is apparent here: on the one hand references to the familial context of conflict and suffering, and on the other the representation of lone male working class masculinity. 
Loyalist murals were slower off the mark in terms of dealing with the issue of victims. In part this derived from the control of mural painting in loyalist areas by military commanders. The loyalist paramilitary groups stated raison d'être was the protection of loyalist communities from republican attacks. In effect, if not in intention, to highlight such attacks and victims was to question the effectiveness of the paramilitary groups. Despite that, there are references to unionists as victims or potential victims of republican attacks. In one mural, an armed loyalist man shields a woman who stands behind him. Two murals refer to an exodus of unionist families to Liverpool in the aftermath of communal violence in Belfast in 1969. And a few murals name the victims, women included, of IRA bombs, such as that at the Enniskillen War Memorial in November 1987 and that at Frizzell's shop on the Shankill Road in October 1993.

\section{Historical}

By far the most common historical theme depicted in republican murals is the Famine of the mid-19th century; most of these murals, 15 in all, contain representations of women. Some, such as that shown in Figure 11, reproduce images from the time, many of which appeared in the Illustrated London News. One mural refers to the Famine as 'genocide' and 'Ireland's holocaust', while another quotes from Seamus Heaney's poem 'Requiem for the Croppies', written about the 1798 rebellion rather than the Famine: 'They buried us without shroud or coffin'. 


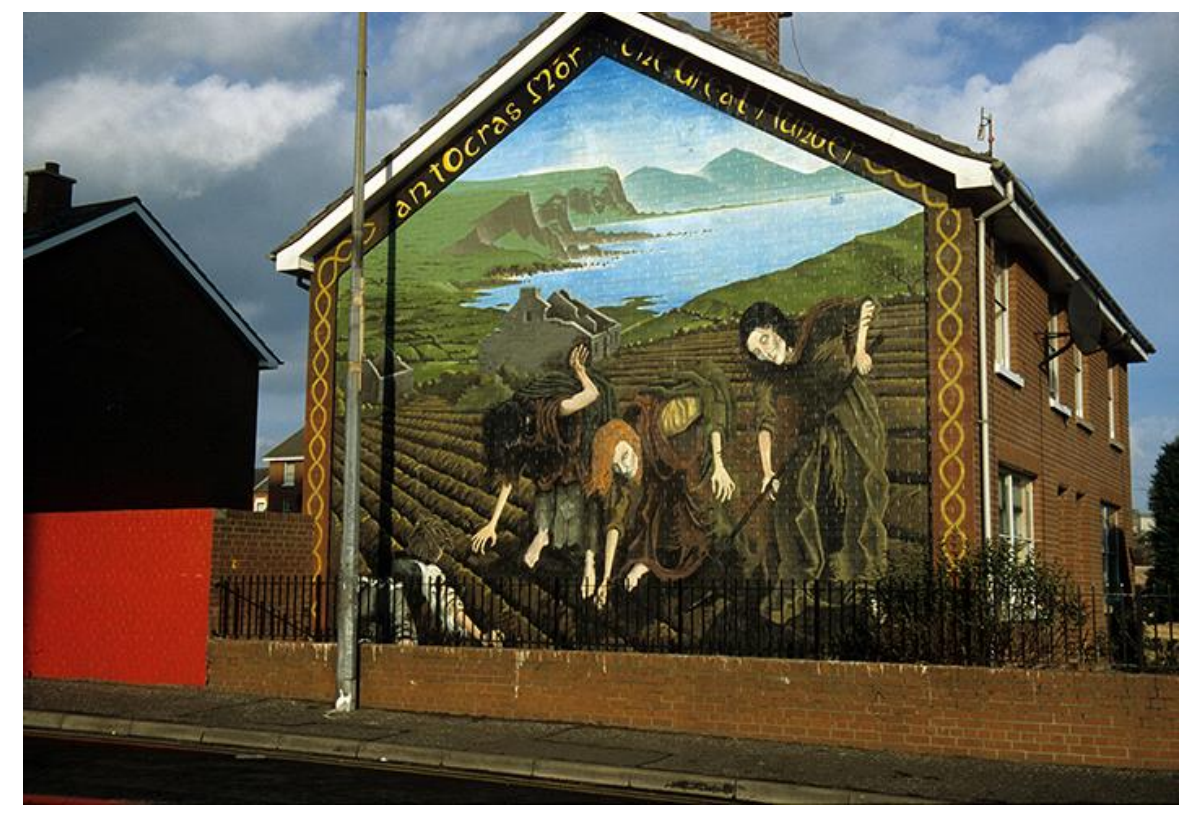

Figure 11. New Lodge Road, Belfast 1995

The next most common theme is the Easter Rising of 1916. This is referred to throughout the period but came to a crescendo in 2016 on the centenary of the event. In all, 12 murals on the theme depict women. These include Countess Marciewicz, the only woman in the leadership of the rebellion (three murals), Winifred Carney, secretary to another leader, James Connolly (five murals) and the Corr sisters from Belfast, members of Cumann na mBan (three murals). Other women from the republican historical pantheon have also been painted: Mary Ann McCracken, republican and feminist in late 18th and early 19th century Belfast, Sarah Curran, the lover of Robert Emmet, leader of the 1803 rebellion, and Anne Devlin, Emmet's housekeeper who was imprisoned and tortured.

Beyond the specific history of republicanism, the only other historical murals in which women feature relate to the penal laws of the 18th century, designed to keep the native Irish population marginalised and impoverished. Three such murals depict the Mass rock, where priests held Catholic liturgy secretly while some of the congregation kept watch for soldiers, 
and one mural shows the hedge schools, where itinerant teachers taught peasant children in the open or in makeshift accommodation.

The penal laws followed on the victory of King William at the Battle of the Boyne. When the Irish forces surrendered in 1691, they were given favourable terms. But these were overturned by the British four years later, leading the Irish to speak of 'perfidious Albion'. The phrase has its contemporary echoes (Hillyard 2002), not least in a number of murals which condemn British actions in Ireland - whether those of Queen Victoria during the Famine, Secretary of State Mo Mowlam during the Orange parade controversies of the late 1990s, or Secretary of State Teresa Villiers in refusing to concede a public inquiry into the massacre of 11 women and men in Ballymurphy in 1971.

Partially connected to the historical theme are those murals which deal with Celtic mythology. Queens Meabh of Connaught and Macha of Armagh, the goddess Éiru and the Children of Lir have all been represented. Mother Ireland has also been a central figure in at least seven murals.

History has proven a rich field in recent loyalist mural painting. For example, murals relating to World War 1 and in particular the Battle of the Somme are numerous. Given that the original UVF, formed to oppose Home Rule, enlisted in the British army as the 36th Ulster Division and suffered huge casualties at the Somme in July 1916, this is not surprising. Relatively few of these Somme murals depict women. Those that do show women nurses tending dying soldiers on the battlefield or sweethearts bidding goodbye to soldiers. One unique mural portrays women munitions workers during that war (see Figure 12). Paradoxically the only person shown actually working with munitions is a man, while the woman seems more concerned with arranging her hair for us the viewers. 


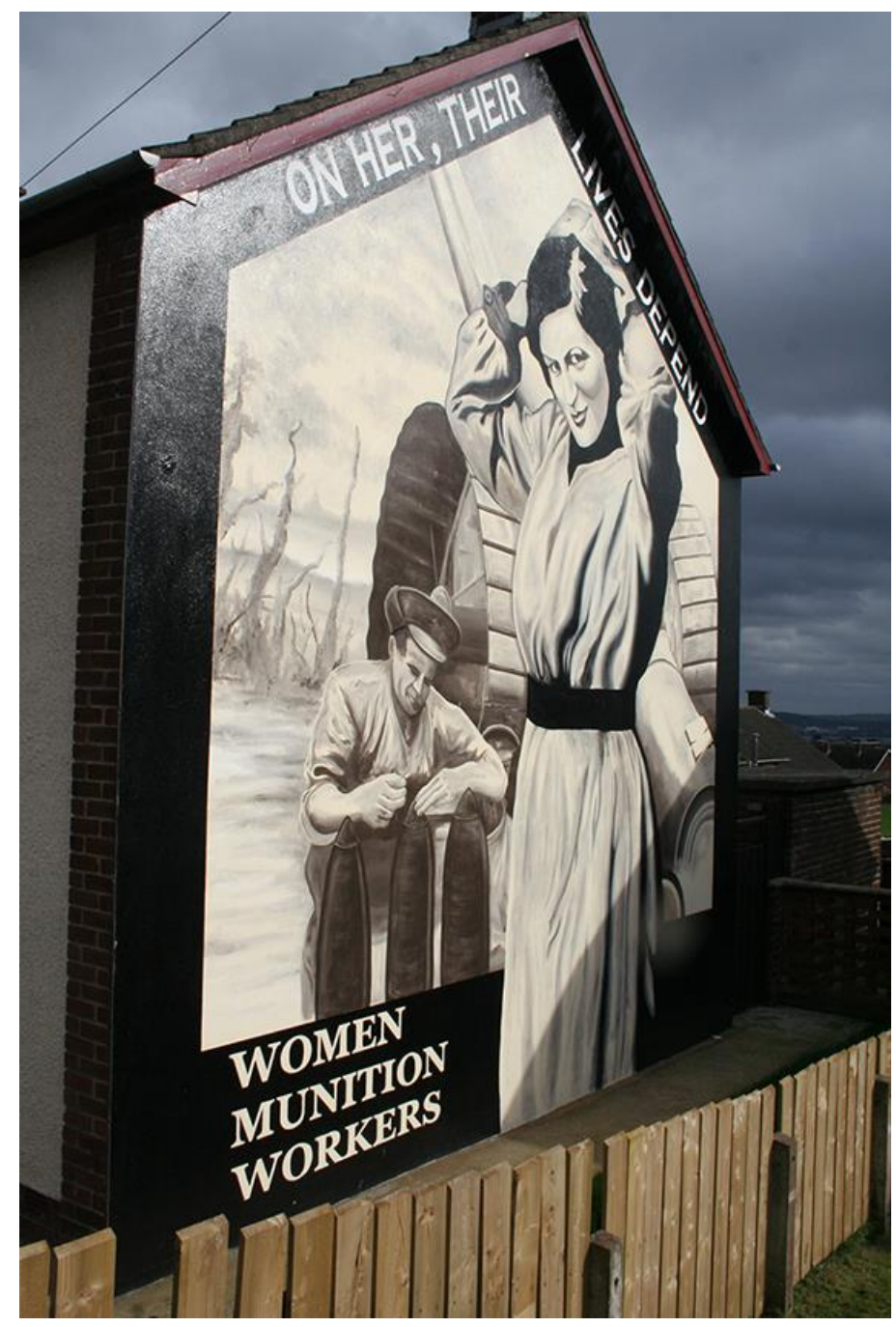

Figure 12. Inniscarn Drive, Newtownabbey 2012

Finally, there have been three murals on Ulster-Scots history which have contained images of women. Disgruntled Protestant planters from Ulster in the 18th century emigrated to America seeking a better life. Two of the murals depict the settlers in the new world heading across the plains in wagons, while one shows a peasant woman by an Irish cottage overlooking a bay (see Figure 13). 'Home is where the heart is' says the accompanying slogan in Ulster-Scots dialect: 'Hame is whaur tha hairt is'. Without the accompanying text one could be forgiven for reading the mural as a kitsch representation of Irish Catholic emigration a century later. 


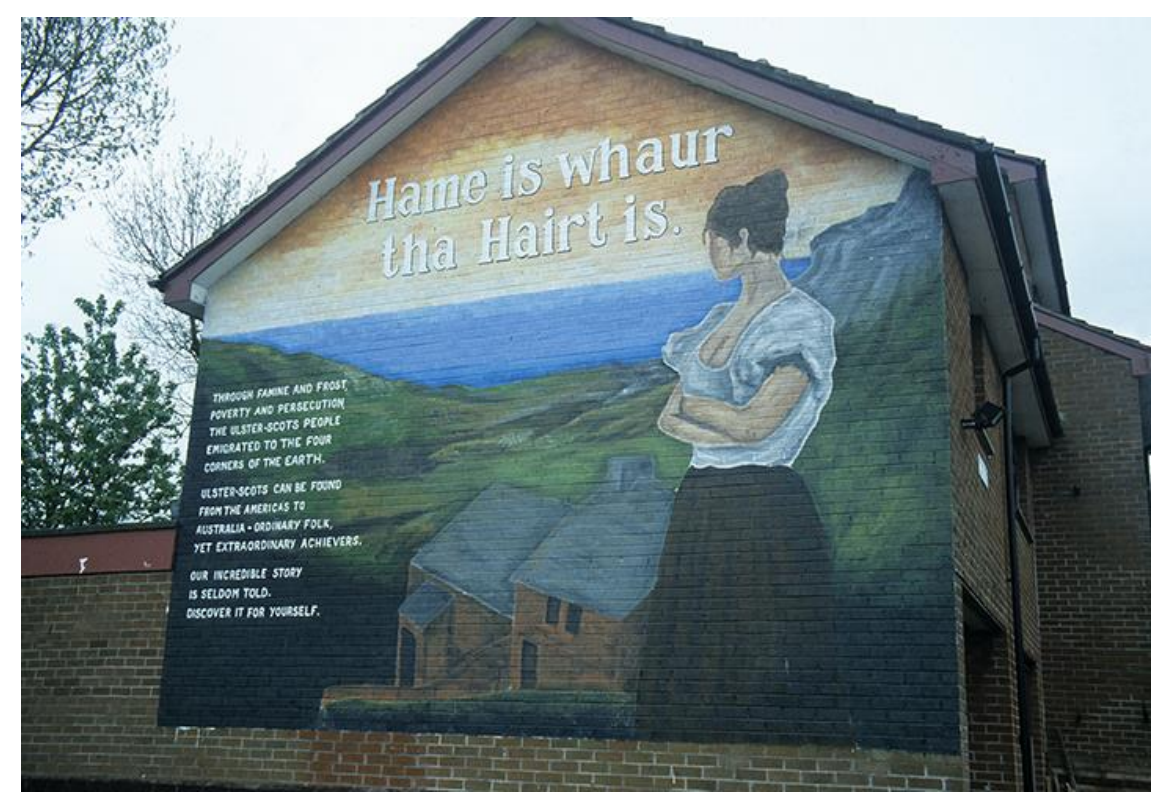

Figure 13. Ballyearl Drive, New Mossley 2002

One class of women has central place in 11 loyalist murals - royalty. Nine of these depict Queen Elizabeth II, most of them painted at the time of her Golden Jubilee in 2002. One mural commemorates Queen Elizabeth the Queen Mother who died in 2002, and a further mural the Queen who never was, Princess Diana (see Figure 14).

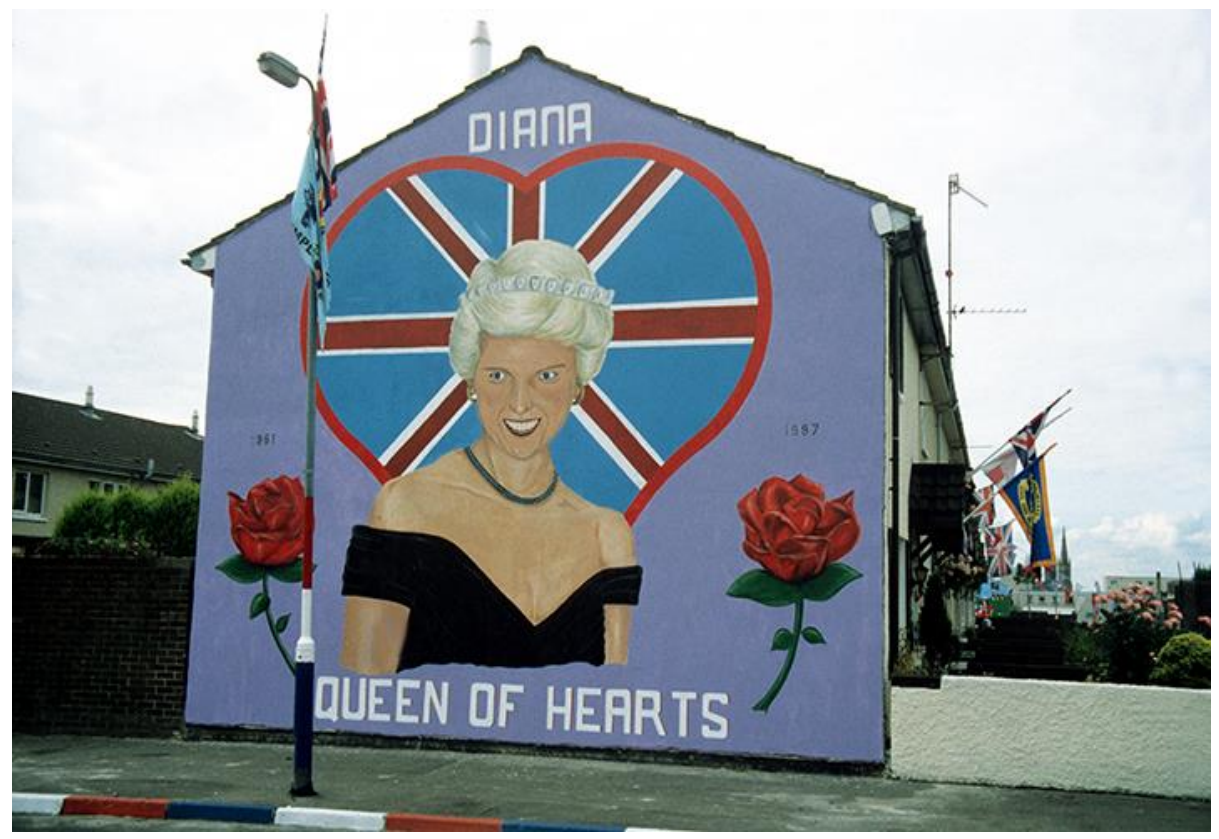


Figure 14. Hopewell Crescent, Belfast 2000

There are five murals which depict Britannia in a celebration of empire which seems oddly anachronistic. The same can be said of the mural shown in Figure 15; the monarch portrayed is not the present one, but her father, King George VI, along with his wife. The World War 11 naval vessels and the lion point to 'postcolonial melancholia' for an empire which no longer exists (Gilroy 2008).

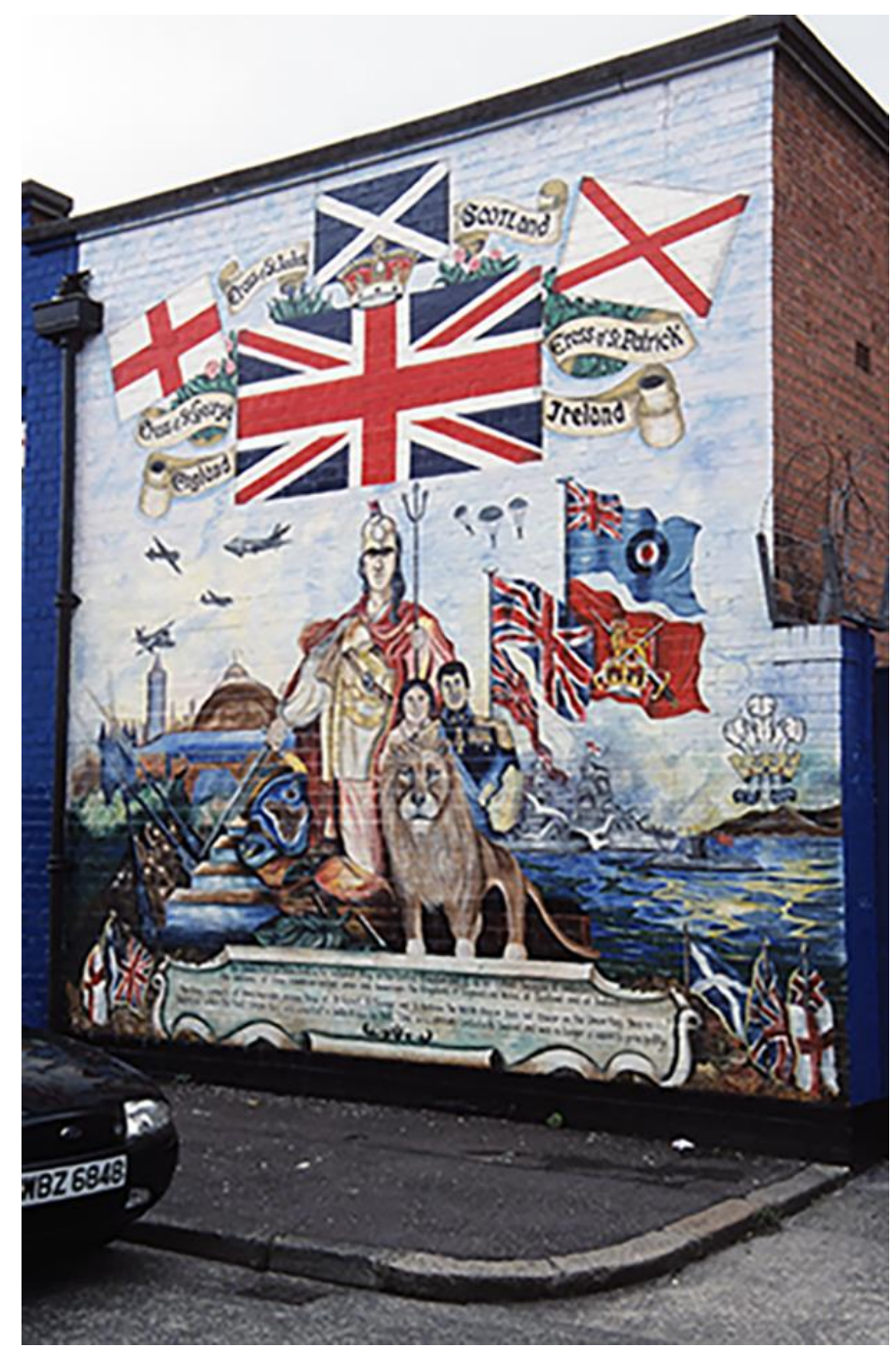

Figure 15. Thorndyke Street, Belfast 2004 


\section{International}

Republican muralists find a resonance with other places where struggles against colonialism, imperialism and repression occur. Women have been represented in such murals from the beginning. Thus, in 1983 a Falls Road mural displayed a female IRA volunteer, a woman from the Palestine Liberation Organisation and a woman from SWAPO, South-West Africa People's Organisation in Namibia, alongside the slogan: 'Women united in armed struggle' (see Figure 16). In later years, other international images appeared, such as a Nicaraguan mother carrying a baby, with a rifle over her shoulder, or a female Turkish hunger striker who died in 2001. US black activist Rosa Parks has been represented in three murals; in one, the accompanying slogan reads: 'She sat down so we could stand up'. The Basque conflict has figured in a number of murals; in one, a Basque woman calls for 'Askatsuna - Saoirse' (Basque and Gaelic for 'freedom').

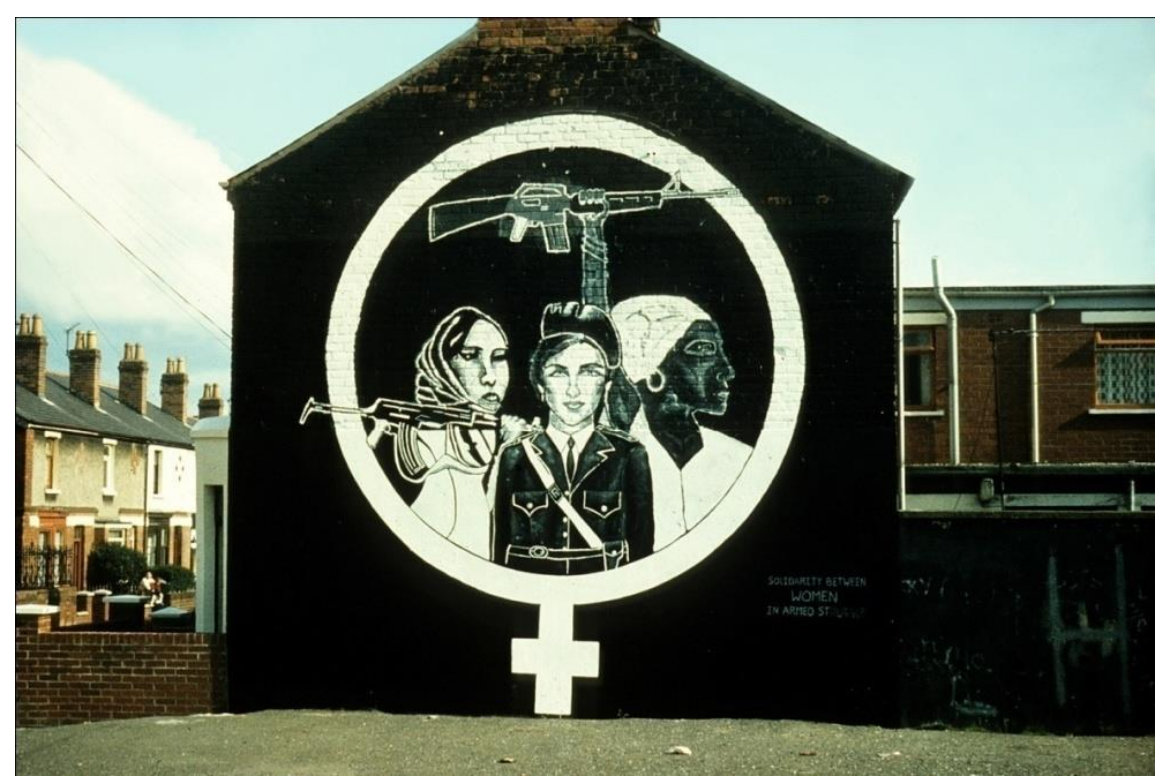

Figure 16. Falls Road, Belfast 1983 
But by far the largest number of murals in this category are about Palestine - 13 in all (see Figure 17). In five of these, Leila Khaled is prominently portrayed. Known as the first female plane hijacker, she was part of a group from the Popular Front for the Liberation of Palestine who hijacked a jet in 1970 which was diverted to London. She was later released in a prisoner exchange and went on to be a politician.

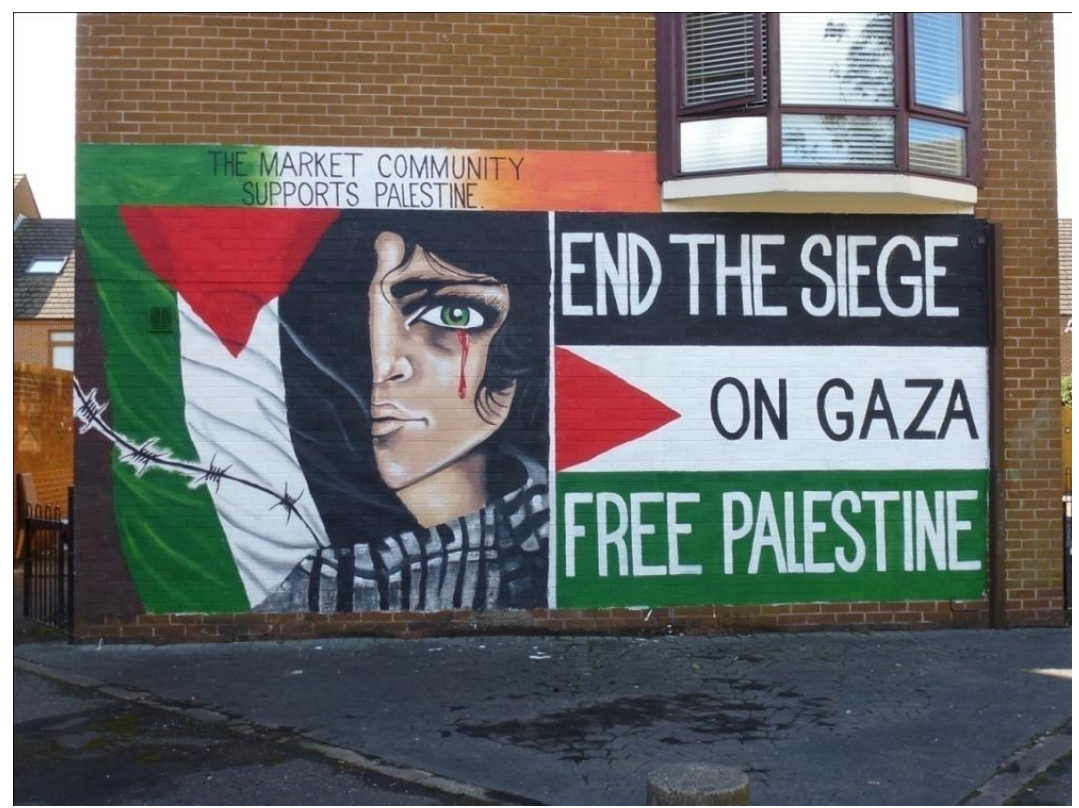

Figure 17. Friendly Street, Belfast 2014

Racism has been tackled directly in six republican murals, whether against refugees or Roma people in Belfast, or against Irish Travellers. In one, Maya Angelou and Mohammed Ali are portrayed alongside Patrick Pearse and James Connolly. And ten murals have raised the demand for women's rights, condemning violence against women, calling for equality, or quoting from James Connolly: 'The worker is the slave of capitalist society. The female worker is the slave of that slave'.

As a political ideology loyalism has great difficulties finding resonances with other societies and struggles. Israel is thus the only international reference to appear in loyalist murals. One 
such display relates to Irishman John Henry Patterson, British army general in charge of the Jewish Legion, precursor to the Israeli Defence Forces (IDF) and depicts a female IDF soldier.

\section{Conclusion}

Mexican muralist David Siqueiros argued that to be effective the message of a mural must be immediately clear (Siqueiros 1975: 123-129). This task is made easier if the producer of the mural and the audience share a common language of symbols. However, murals can impart other messages, not through presence, but through absence. The silence of murals on an issue or topic can speak volumes of the structures of power in a society. If subaltern voices do not have access to public space, if minority groups do not see themselves reflected in public art, if the public display of the views of political opposition is suppressed, then an understanding of that society derives as much from what is not on the walls as from what is.

In the Northern Ireland case, silence works at a number of interconnected levels. Firstly, in the new post-conflict Belfast, memorialisation of the recent conflict is non-existent in the city centre. None of the approximately 70 deaths which occurred there is directly commemorated (Switzer and McDowell 2009). This has profound effects. As many of these dead were civilians, the memorial landscape in Belfast centre plays its part in the underrepresentation of the deaths of civilian women and men (Brown 2010). Memorialisation of conflict is relegated to the mainly working class areas where the conflict was most fierce and where the priority has often been to commemorate dead heroes. As these heroes are more likely statistically to be male, male combatants thus have pride of place on the walls in these areas (McDowell 2008). Finally, there are differences between separate working class areas. As Brown (2014: 
159) notes, the representation of women in republican memorial sites, including murals, goes 'beyond mere tokenism'. At the same time, although 'most women were not campaigners, activists, prisoners or combatants' (Brown 2014:166), these are the women who are the most likely to be commemorated. And if women's representation is partial and skewed in republican areas, it is even more so in loyalist areas. As Dawn Purvis, former leader of the Popular Unionist Party, a party linked originally to the UVF, has noted: 'Women were not allowed to join [and] that is depicted in the murals' (quoted in Ward 2004: 502).

This survey of political murals depicting women confirms the relative absence of women from the walls of Belfast. The murals emanate from two separate communities which have differential political awareness. They thus provide a window into the gender relations in Northern Ireland in general and the differential strength of masculinity between republican and loyalist groups. As befits a political force which, as the conflict progressed, found some space for the incorporation of women in some key positions, republicanism has fared better in terms of representation. Female activists, including combatants, prisoners, victims and historical and mythological women appear in one out of five republican murals over a 35 year period. Confined as it was to a narrower militaristic raison d'être, loyalism was less able to include women in its various tasks and has also been less concerned to represent even the few women involved in their midst. Hence, there is no representation of loyalist prisoners, few of loyalist activists and only one known example of loyalist female combatants in the same time period. References to royalty and Empire, as well as historical women, reinforce the message of unionists as loyalist and royalist. Only one in 200 loyalist murals contain a female figure. Nowhere do women receive representational equality with men, but in relation to loyalist murals, that absence comes close to being tantamount to silence. 
Reading

Alison, M. (2004) Women as Agents of Political Violence: Gendering Security. Security Dialogue 35(4): 447-463

Ashe, F. (2007) Gendering ethno-nationalist conflict in Northern Ireland: A comparative analysis of nationalist women's political protests. Ethnic and Racial Studies 30(5): 766-786

Bloom, M., P. Gill, P. and J. Horgan. (2012) Tiocfaidh ár Mná: Women in the Provisional Irish Republican Army. Behavioral Sciences of Terrorism and Political Aggression 4(1): 6076

Brown, K. (2010) Noncombatants and Memorialization in Post-Conflict Northern Ireland. In: Frawley, O. (ed) Memory Ireland. Volume 1: History and Modernity. Syracuse: Syracuse University Press, 310-323

Brown, K. (2014) Manicured Nails but shackled Hands? The Representation of Women in Northern Ireland's Post-conflict Memory. In: Buckley-Zistel, S. and S. Schafer. (eds) Memorials in Times of Transition. Cambridge: Intersentia, 149-170

Corcoran, M. (2006) Out of Order: The political imprisonment of women in Northern Ireland 1972-1998. Cullompton: Willan Publishing 
Coulter, C. (1999) Contemporary Northern Ireland Society: an Introduction. London: Pluto Press

Del Zotto, A. (2002) Weeping Women, Wringing Hands: How the Mainstream Media Stereotyped Women's Experiences in Kosovo. Journal of Gender Studies 11(2): 141-150

Farr, V. (2002) Gendering Demilitarization as a Peacekeeping Tool. Bonn: Bonn International Centre for Conversion.

Fearon, K. (1999) Women's Work: the Story of the Northern Ireland Women's Coalition. Belfast: Blackstaff Press.

Fontanella-Khan, J. (2009) Women fighters in Nepal. Financial Times, 26 September

Gilroy, P. (2008) Postcolonial Melancholia. New York: Columbia University Press

Haeri, M. and N. Puechguirbal. (2010) From helplessness to agency: examining the plurality of women's experiences in armed conflict. International Review of the Red Cross 92(877): $103-122$

Hamber, B. and I. Palmary. (2009) Gender, Memorialization and Symbolic Reparations. In: Rubio-Marín, R. (ed) The Gender of Reparations. Cambridge: Cambridge University Press, $324-382$

Hillyard, P. (2002) Perfidious Albion: Cover-up and collusion in Northern Ireland. Statewatch 221 June: http://www.statewatch.org/news/2002/jun/09ni.htm 
Kelly, W. (2001) Murals: The Bogside Artists. Derry: Bogside Artists

Killen, J. (1985) John Bull's Famous Circus: Ulster History through the Postcard, 19051985, Dublin, O'Brien Press

Koth, M. (2005) To End a War: Demobilization and Reintegration of Paramilitaries in Colombia. Bonn: International Centre for Conversion.

Larkin, E. (1972) The Devotional Revolution in Ireland, 1850-75. The American Historical Review 77(3): 625-652

McDowell, S. (2008) Commemorating dead "men": gendering the past and present in postconflict Northern Ireland. Gender, Place and Culture 15(4): 335-354

McEvoy, S. (2009) Loyalist Women Paramilitaries in Northern Ireland: Beginning a Feminist Conversation about Conflict Resolution. Security Studies 18: 262-286

McKittrick, D. et al., (1991) Lost Lives: The stories of the men, women and children who died as a result of the Northern Ireland troubles. Edinburgh: Mainstream Publishing

Murphy, E. (2011) The Gender Pay Gap, Northern Ireland Assembly Research Paper NIAR 373-2011, 1 August 
O'Keefe, R. (2013) Feminist Identity and Activism in Revolutionary Movements. London: Palgrave MacMillan

Pankhurst, H. (n.d.) Gender and Conflict: Case Study on Eritrean Ex-fighters. http://www.acord.org.uk/gender_conflict_paper.doc

Patterson, H. (2013) Ireland's Violent Frontier: The Border and Anglo-Irish Relations During the Troubles. London: Palgrave Macmillan

Potter, M. (2014) Who Runs Northern Ireland? A Summary of Statistics Relating to Gender and Power, Northern Ireland Assembly Research Paper 79/14, 19 June

Racioppi, L. and K. O'Sullivan See. (2000) Ulstermen and Loyalist Ladies on Parade: Gendering Unionism in Northern Ireland. International Feminist Journal of Politics 2(1): 129

Restrepo, E. (2016) Leaders against all odds: Women victims of conflict in Colombia. Palgrave Communications 2, 2016 doi:10.1057/palcomms.2016.14

Rolston, B. (1992) Drawing Support: Murals in the North of Ireland. Belfast: Beyond the Pale Publications

Rolston, B. (1995) Drawing Support 2: Murals of War and Peace. Belfast: Beyond the Pale Publications

Rolston, B. (2003) Drawing Support 3: Murals and Transition in the North of Ireland. Belfast: Beyond the Pale Publications 
Rolston, B. (2010) "“Trying to reach the future through the past": Murals and memory in Northern Ireland', Crime, Media, Culture 6(3): 285-307

Rolston, B. (2013) Drawing Support 4: Murals and Conflict Transformation in Northern Ireland. Belfast: Beyond the Pale Publications

Rooney, E. (1995) Political Division, Practical Alliance: Problems for Women in Confict. Journal of Women's History 6(4): 40-48

Ross, F. (2011) Smashing H Block: the Rise and Fall of the Popular Campaign against Criminalization 1976-1982. Liverpool: Liverpool University Press

Roulston, C. (1989) Women on the Margin: The Women's Movement in Northern Ireland. Science and Society 53(2): 219-236

Shirlow, P. and K. McEvoy. (2008) Beyond the Wire: Former Prisoners and Conflict Transformation in Northern Ireland. London: Pluto Press

Siqueiros, D. (1975). Art and Revolution. London, London: Lawrence and Wishart

Sjoberg. L. (2016) Women as Wartime Rapists: Beyond Sensation and Stereotyping. New York University Press

Stiehm, J. (2014) Champions for Peace: Women Winners of the Nobel Peace Prize. Lanham, Rowan and Littlefield

Stringer, R. (2014) Knowing Victims: Feminism, Agency and Victim Politics in Neoliberal Times. London: Routledge 
Switzer, C. and S. McDowell. (2009) Redrawing cognitive maps of conflict: Lost spaces and forgetting in the centre of Belfast. Memory Studies 2(3): 337-353

Ward, M. (1989) Unmanageable Revolutionaries: Women and Irish Nationalism. London: Pluto

Ward, M. (1991) The Women's Movement in the North of Ireland: Twenty Years On. In: Hutton, S. and Stewart, P. Ireland's Histories: Aspects of State, Society and Ideology. London, Routledge: 149-163

Ward, R. (2004) 'It's Not Just Tea and Buns': Women and Pro-union Politics in Northern Ireland. British Journal of Politics and International Relations 6: 494-506

WRDA (2015) Celebrating Belfast Women: a City Guide through Women's Eyes. Belfast: Women's Resource and Development Agency

Whitaker, R. (2008) Gender and the Politics of Justice in the Northern Ireland Peace Process: Considering Róisín McAliskey. Identities: Global Studies in Culture and Power 15: 1-30 Yuval-Davis, N. and F. Anthias. (1989) Women-Nation-State. London: Macmillan 